\title{
Pragmatics and Language Teaching
}

\author{
Raifu O. Farinde \\ Department of English and Literary Studies, Federal University Oye-Ekiti, Nigeria \\ Wasiu A. Oyedokun-Alli \\ Department of English and Literary Studies, Federal University Oye-Ekiti, Nigeria
}

\begin{abstract}
The main goal of language teaching is that at the end of the period of learning, the learners should be able to communicate in that language effectively. The main source of language is language use. The students must therefore be given plenty of opportunity to use the language. This is where the principles of pragmatics come into language teaching. Pragmatics provides ample opportunities for the students to learn English language communicatively and practically. In this study, I shall focus particularly on the application of pragmatics to language teaching with emphasis on Gricean pragmatics and Searle's speech acts. The question of why pragmatics should be assigned a more prominent place in language teaching syllabus is also sufficiently and adequately addressed.
\end{abstract}

Index Terms - pragmatics, language teaching, speech acts, communicative skills

\section{INTRODUCTION}

The major target of language teaching is that at the end of the period of learning, the learners should be able to communicate in the target language effectively. The new priorities of language teaching are the real uses of language, especially social uses. In the recent years, communicative approach has started gaining grounds. Finochiaro and Brumfit (1983:9) aver that the two assumptions that underlie this approach are: "that we are concerned in the classroom with language use, not language knowledge; the second is the view that we learn language most effectively by using it in realistic situations". In this approach, far less attention is given to systematic mastery of sounds and structures. Also, the focus is not on skills of reading and writing. This is because whether you engage your students in the systematic mastery of sounds and structures, or reading or writing, you are guiding your students towards the same target. The main source of progress is the actual use of language.

The implication of the above submission is that the students must be given plenty of opportunities to use the language. The language teacher must evolve a strategy of involving the students in frequent and effective practice of the target language. Dekert (1987:18) asserts that the teacher's strategies of involving the students in frequent and effective practice of the target language begin with any one or combinations of the following; (i) regular use of the language to conduct class activities, (ii) dramatic demonstration of different practice devices for obtaining functional use of the language, (iii) appropriate discussion of how people in general and different individuals in particular best learn another language, (iv) class statement of the more appropriate roles of memory work in the acquisition process (v) resolute prevention of the thoughtless copying of illustrative language samples in place of active listening to another, (vi) systematic assignment of homework tasks that elicit creative though imperfect, uses of language, (vii) frequent use of short quizzes of communicative character, both oral and written, (xiii) gradual inclusion of original communicative tasks on major examinations, and (ix) careful avoidance of test items for which fixed answers might be anticipated and memorized.

From the above, we can glean the fact that the ability to use language in a communicative way includes the ability to produce and understanding utterances that are many sentences long and to engage in verbal exchanges of great variety and that is why pragmatics is very important in communicative language teaching. Farinde (2010) argues that part of the job of pragmatics is to describe how longer utterances and verbal exchanges cohere internally, what kinds of communicative functions they perform and how they are rule governed. Its domain of analysis, in short, is ultimately discourse, not sentence.

But before going to pragmatics and language teaching proper, it is necessary as a first step to review communicative approach properly with a view to show its relationship with pragmatics and language teaching.

Advancing Communicative language teaching

It is as a result Chomsky's criticism of structural linguistic theory in his classic book 'Syntactic Structures' (1957) that led to the birth of communicative language teaching. Chomsky had suggested that the current standard structural theories of language were incapable of accounting for the fundamental characteristics of language-the creativity and a uniqueness of individual sentences.

According to Richards and Rodgers (1995), British applied linguists, then, emphasized another fundamental dimension of language that was inadequate in addressing current approaches to language teaching at that time-the functional and communicative potential of language. They saw the need to focus in language teaching on 
communicative proficiency, rather than on mere mastery of structures. Scholars who advocated this view of language, such as Christopher Cardin and Henry Widdowson, drew on the work of British functional linguist (e.g. John Firth, M.A.K. Halliday), American work in sociolinguistics (e.g. Dell Hymes, John Gumperz and William Labov), as well as work in philosophy (e.g. John Austin and John Searle).

In addition to this, D.A. Williams (1972) also proposed a functional or communicative definition of language that could serve as a basis for developing communicative syllabuses for language teaching.

Another linguist theory of communication favoured in communicative language teaching is Halliday's functional account of language use. According to Halliday (1970) Linguistics is concerned with the description of speech acts or texts, since only through the study of language in use are all functions of language, and therefore all components of meaning brought into focus. His powerful theory of functions of language is as cited by Richard and Rogers (1995):

1. The instrumental function: using language to get things;

2. The regulative function: using language to control the behaviour of others;

3. The interactional function: using language to create interactions with others;

4. The personal function: using language to express personal feelings and meanings;

5. The heuristic functions: using language to learn and discover;

6. The imaginative function: using language to create a world of the imagination;

7. The representational function: using language to communicate information.

Richards and Rodgers (1995; 70-71).

Finochiaro and Brumfit (1983) cited in Farinde (2010) outline all the properties underlying communicative approach and they are enumerated below:

\section{Communicative language teaching}

i. Meaning is paramount

ii. Dialogs, if used, centered around communicative functions and are not normally memorized.

iii. Contextualization is a basic premise.

iv. Language learning is learning to communicate

v. Effective communication is sought.

vi. Drilling may occur, but peripherally.

vii. Comprehensible pronunciation is sought.

viii. Any devise which helps the learners is accepted-varying according to their age, interest, etc.

ix. Attempts to communicate may be encouraged from the very beginning

$\mathrm{x}$. Judicious use of native language is accepted where feasible.

xi. Translation may be used where students need or benefit from it.

xii. Reading and writing can start from the first day, if desired.

xiii. The target linguistic system will be learned best through the process of struggling to communicate.

xiv. Communicative competence is the desired goal (i.e the ability to use the linguistic system effectively and appropriately)

$\mathrm{xv}$. Linguistic variation is a central concept in materials and methodology

xvi. Sequencing is determined by any consideration of content, function, or meaning which maintains interest.

$\mathrm{xvii}$. Teachers help learners in any way and that motivates them to work with the language.

xviii. Language is created by the individual often through trial and error.

xix. Fluency and acceptable language is the primary goal: accuracy is judged not in the abstract but in context.

xx . Students are expected to interact with other people, either in the flesh, through pair and group work, or in their writings.

xxi. The teacher cannot know exactly what language the students will use.

xxii. Intrinsic motivation will spring from an interest in what is being communicated by the language.

$(1983: 91-3)$

\section{Pragmatics And Language Teaching}

Ekpa (1996:179) reiterates that the communicative approach has some overriding advantages. One of which is that it emphasizes the teaching of fluent English. While other methods promote the teaching of accuracy, that is the ability to produce correct sentences, the communicative approach ensures that the learner is able to speak and write with ease and is also able to engage in continuous speech that is intelligible rich in grammar, vocabulary and shows a good command of intonation.

Ekpa (1996:179) advises that students in elementary and secondary schools should be made aware of the factors of social acceptability of language use which is a major premise of communicative competence. Since the communicative approach emphasizes situationalization of language as opposed to emphasis on form, Ekpa suggests that students should be taught to recognize the situations and circumstances in which different kinds of language are appropriate and should be given practice in using the proper linguistic forms according to those contexts.

From the discussion above, we can observe the fact that the principles of pragmatics are so indispensable in communicative language teaching. In order for communicative language teaching to be highly effective pragmatics is a 
very crucial discipline for language teachers to understand and be using in the classrooms. In support of this, Zagarac (2002:12) states that 'it is difficult to see pragmatics as irrelevant to a profession so centrally and essentially concerned with people and language use. Teaching and learning are always mediated through language; so, theories of communication precisely expressed by those trained philosophers who have turned their attention to the practical instinct interest to all teachers cannot but be highly useful. For language teachers, however, they are of relevance not only for insight into the process of teaching and learning through communication but also for a consideration of what is being taught'.

Nunn (2006) affirms that Pragmatics is applicable to language teaching because classroom language teaching is an occupation which essentially uses language in a social context. English language teaching practitioners should therefore much more than before consider the ever-increasing variety of contexts in which users across the globe are learning and using English pragmatically. According to Nunn, theories of practice that shed light on how language is used in context and how people negotiate understanding, however different they may be in ability, culture, and status are essential to our social and professional understanding. In this discussion, We shall focus on Gricean pragmatics in relation to language teaching

Cooperative principles and their maxims according to Nunn (2006) were never intended to be seen as a set of rules to be obeyed but could ostensibly still serve as useful guiding principles for teachers. Teachers and students, as normal human beings, deliberately flout them or unwillingly violate them, but it is still useful to have them as a point of reference. The cooperative Principles (CP) and their conversational maxims are presented below according to Grice (1975). The principle focuses on four major areas- relation, quantity, quality and manner.

\section{CoOPerative PRINCIPLE (GRICE 1975)}

Make your conversational contribution such as it required, at the stage at which it occurs, by the accepted purpose or direction of the talk-exchange in which you engage.

1. Relation-Be relevant

2. Quality- Do not say what you believe to be false. Do not say that which you lack evidence

3. Quantity- Make your contributions as informative as is required. For the purpose of the exchange, do not make your contribution more informative than is required.

4. Manner- i avoid obscurity of expression

ii avoid ambiguity

iii be brief

iv be orderly.

Tswanya (2010:339) affirms that 'to Grice and his adherents, one reason why what is said in conversation discourse makes sense in spite of the missing implicit element is the cooperative principle which usually operates between speaker/hearer and writer/reader in interactive conversation'. Goffman (1976) also supports this by noting that communication cannot truly work unless participants generally observe four major norms of cooperation: relevance, truthfulness, quantity and clarity. We will take the maxims one after the other for proper discussion on their relevance to language teaching.

\section{A. Maxim of Relevance}

This maxim orientate interlocutors to organize their utterances in such a manner that they are relevant to the ongoing discourse: Be relevant at the time of utterance. Let us consider the following two examples from Ogunsiji and Farinde (2010: 90-91):

1. A: Where is my box of chocolates?

$\mathrm{B}$ : It is in your room

2. A: Where is my box of chocolates?

B: The children were in your room this morning.

Example (1) above is relevant in a straightforward way. In (2) B's remark can as well be made relevant to A's question on the ground that supposing A does not know the answer, B's reply will nevertheless help 'A' to discover the answer by implicating that the children may have eaten the chocolates or at least may have known where they are. But in the following example, there, there is a violation of this maxim:

Kunle: How are you getting along with the work?

Dele: There is a party tonight.

On face value, Dele's reply seems unrelated to what Kunle has asked. In this regard, Dele has flouted the maxim of relation. This maxim of relevance is highly useful in language teaching particularly in the teaching of writing skills. According to Hatch (1992) in writing, only one person is building the text, trying to put information into an appropriate sequence so that the pieces most highly related to each come together. Writers can use paragraph markers to do some of the work. Each new paragraph shows a slight shift in focus so that the sentences within it relate more directly to each other. Each paragraph in turn relates in some organized way to the overall topic of the discourse.

A language teacher can use this maxim of relevance to advantage in the teaching of writing. White (2001) provides a detailed description of a course design based on Gricean maxims showing how the maxims of spoken interaction can be 
applied to the teaching of writing, as cited in Nunn (2006). The qualities White refers to - clarity, brevity, relevance and sincerity- are arguably usefully by any writers. Nunn (2006) also notes that writing often tends to be more efficient than speech and Grice's theory as well as relevance theory might seem to be almost more suited to issues of efficient written communication.

In a similar manner, Tswanya (2010) also examines the impact of training intervention on improving writing competence of advanced ESL/EAP students through the use of Grice's maxims of quality, quantity, relevance and manner. The result shows that training and sensitization on Grice's maxim of cooperative principles impacted positively on students' writing competence.

From the above, we can see that Grice's cooperative principle particularly the theory of relevance can benefit writing a lot. In the primary and secondary schools, students essay writing will be meaningless if what they are writing are not relevant to the overall theme of the essay question. In Twanya's study, he discovers that experimental groups taught with Grice's cooperative principles produce better reader-friendly writing which meets the reader's expectation of clarity, brevity and sincerity. Their written products were also more devoid of superflousness often characteristics of inexperienced and poor writers. Also, for teachers to be efficient in their teaching, they must teach what is relevant to their students.

\section{B. Maxim of Quality}

Maxim of quality emphasizes the virtue of truthfulness. Interlocutors are expected to say only what they believe to be true and to have evidence for what they say. Gough (1984) affirms that when we violate truthfulness, we often do so using special intonation for sarcastic, for teasing, or for playfulness.

This maxim is also very important for language teaching. It is highly useful for language teachers in the sense that a teacher's prolixity or sarcastic could become a norm for defining or checking the maxim of quality. Apart from this, maxim of quality is indispensable in the teaching of young children. This is because the ability to take on another role in pretence appears very early in child development. Hatch (1992) affirms that, learning how to move in and out of 'truthfulness' with appropriate marking may be acquired early in life but the successful execution and recognition of irony, teasing, and joking is not an easy matter even in adulthood. The markings are not always easy for language learners to recognize. Pretence, teasing, and joking may be quite difficult for many learners. The knowledge of the maxim of quality will be highly helpful here for both the young and adult learners in these areas.

\section{Maxim of Quantity}

It is normally assumed that people are going to provide an appropriate amount of information but it is not always so because everyone wants to have his or her 'fair' share of talk time. However, speakers are expected to give as much information as is necessary for their interlocutors to understand their utterance but to give no more than is necessary. In speech, this is always difficult for interlocutors. Let us consider the following example from Yule (1996:36):

Man: Does your dog bite?

Woman: No

(The man reaches down to pet the dog. The dog bites the man's hand)

Man: Ouch! Hey, you said your dog does not bite

Woman: He doesn't. But this is not my dog

(Yule 1996:36)

In the example above, from the man's perspective, the woman provides less information than expected. This maxim is also very important in the teaching of writing to language learners.

Hatch (1992) maintains that in writing, some of us are very long- winded, while others are too brief. It is difficult to judge exactly how much inferencing or reading between the lines' we can ask our readers to do. We want to be brief, but not so brief that our message isn't clear.

\section{Maxim of Manner}

This maxim relates to how what is said is to be said. It also supports the maxim of relation. It tries to avoid obscurity and ambiguity. It is as well tries to be brief, clear and orderly in presentation. In classroom teaching, especially the teaching of writing compositions and essays, this maxim is indispensable. It is so important that almost what the teachers need on students' essays and compositions are embedded in it. Orderliness, clarity, avoidance of obscurity and ambiguity are always specified by language teachers in the teaching of writing of compositions and essays. Let us take the following example from Finegan (2014:309)

A birthday cake should have icing; use unbleached flour and sugar in the cake;

bake it for one hour; preheat the oven to 325 degrees; and beat in three fresh eggs.

In the above example, what is actually wrong in it is that it does not follow a chronological order of events in its description. Further examples that buttress the fact that orderly and logical presentation of ideas is very important in writing are:

1. The policeman died and was struck down by a hit and run car.

2. Dele and Kemi had a baby and got married. 
What is odd in the above examples are the simple fact that the two examples do not follow the rule of orderliness in sequence of events which maxim of manner is advocating.

It is normal to say:

1. The policeman was struck down by a hit and run car and died

2. Dele and Kemi got married and had a baby.

From the discussion above, we can glean the fact that it is very important that students should construct their essays and compositions in an orderly way. They should also make sure that their writings are clear, unambiguous and not obscure. Language teachers must be made to be aware that this is what the maxim of manner is teaching and they should always be making use of it in the classroom.

\section{CONCLUSION}

This paper has considered the application of Gricean maxims to language teaching. Language teachers can benefit from precision and rigour provided by trained philosopher such as Grice as an aid to understanding and operationalizing key concepts such as Gricean maxims. This study has attempted to outline the relevance of pragmatic theory to language teaching. A detailed awareness of the pragmatic meaning of maxims of relevance, quality, quantity and manner precisely defined within a coherent theory of communication can provide important insights into how to provide the kind of classroom activities and tasks that are both of practical interest and based on a sound theory of communicative practice.

\section{REFERENCES}

[1] Chomsky, N. (1957). Syntactic Structures Oxford: Claredon Press.

[2] Dekert G. (1987). "Effective Interviewing in the communicative classroom". Forum Vol. XXX, No3 Pp12-16.

[3] Ekpa, A. (1996). "Attaining Oral communicative competence by learners of English as a second language: Some Psycholinguistic and Sociolinguistic Approaches". In Orisawayi, D. Ogu, J. And Essien A. (eds) Approaches to Oral English \& Communication skills. Calabar: University of Calabar press Pp 175-183.

[4] Farinde R.O. \& Ojo J.O. (2010). "Communicative Language Teaching: A Pragmatic Approach in a Democratized Nigeria" In South-West Journal of Teacher Education (SOWEJTED) (3) Pp. 478-513

[5] Finegan, E. (2014). Language: Its Structure and Use. Boston: MA Wadsworth.

[6] Finochiaro, M. And Brunfit C. (1983). The functional notional approach: from theory to practice. New York: Oxford University Press.

[7] Goffman. E. (1976). Replies and Responses. Language in Society 5, 3:254-313.

[8] Grice, H.P. (1975). "Logic and Conversation" In P. Cole \& J. Morgan (eds) Syntax and Semantics 3 Speech-Acts New York: Academic Press Pp 41-58.

[9] Halliday, M.A.K. (1970). Language Structure and Language function. In Lyons J. (ed) New horizons in Linguistics.

[10] Hatch, E. (1992). Discourse and Language Education. Cambridge: Cambridge University Press.

[11] Nunn, R. (2006). Pragmatics of Cooperation and Relevance for Teaching and Learning. The Linguistic Journal (1) Pp 31-35

[12] Ogunsiji Y. \&Farinde, R.O. (2010). Analytical Linguistics. Ago Iwoye: Olabisi Onabanjo University Press.

[13] Richards, J.L \& Rodgers T.S. (1995). Approaches and methods in language teaching. Cambridge: Cambridge University Press.

[14] Tswanya, S. (2010). "Grice's maxims of cooperative principles \& the teaching Writing competence" In Ndimele (ed) English studies \& national development in Nigeria Pp 335-352

[15] White, R. (2001). “Adapting Grice's maxims in the teaching of writing. ECT Journal 55 (1) Pp 62-69.

[16] Williams, D. (1990). English language teaching: An integrated approach. Ibadan: Spectrum Books.

[17] Yule, G. (1985). The Study of Language. Cambridge: C.U.P.

[18] Zagarac, V. (2002). "Pragmatics in teaching". In N. Schmitt (ed.) An introduction to applied linguistics. London: Edward Arnold. Pp 1-18.

Raifu O. Farinde was born in Erin- Osun, Osun State, Nigeria on March 4, 1970. He attended Adeyemi College of Education, Ondo, Nigeria, between 1988 and 1992 for his Bachelor's Degree in English Education. He obtained his M.A in English Language from the University of Ibadan, Nigeria in 1998. He also bagged his PhD in Linguistics and English Language from the University of Wales, Bangor, United Kingdom now Bangor University, Bangor, United Kingdom in 2007.

He currently lectures at the Department of English and Literary studies, Federal University Oye-Ekiti, Nigeria. He has worked at Adeyemi College of Education, Ondo, Nigeria and he left there as a Chief Lecturer. At present, he is a Senior Lecturer at the Federal University Oye-Ekiti, Nigeria. Among his published works includes Forensic Linguistics: An introduction to the Study of Language and the Law Allemagne, Germany: LIMCOM GMBH, 2009. He also co-authored with Dr. Ojo J.O. Introduction to Sociolinguistics Ondo, Nigeria: Lektay Publishers, 2005. Furthermore, He co-authored with Dr. Yemi Ogunsiji Analytical Linguistics Ago-Iwoye, Nigeria: Olabisi Onabanjo University Press. 2010. His research interests include Pragmatics, Forensic Linguistics, Discourse Analysis, Sociolinguistics and Systemic Functional Grammar.

Dr. Farinde is a member of several learned societies some of which are British Association of Applied Linguistics (BAAL), Linguistic society of America (LSA), Nigeria English Studies Association (NESA) and English Language teachers Association of Nigeria (ELTAN). He is a recipient of Ford Foundation International Fellowship for PhD organized by the Institute of International Education (IIE) New York between 2003 and 2006. Among his awards, honours and distinctions are Certificate of Achievement, UK, 2005, Certificate of Completion, 2004, Certificate of Recognition, 2013. 
Oyedokun Alli Wasiu Ademola is Senior Lecturer in English and Linguistics and currently the Acting Director-General Studies Unit of Federal University Oye-Ekiti, Nigeria. He holds a doctorate degree from the Ahmadu Bello University, Zaria in the Year 2010. He also studied Law at the University of Ibadan. 2002-2007. He was called to the Nigerian Bar in the Year 2008, having passed the Bar Finals the same Year. He was at different times, Adjunct Senior Lecturer at different times, Adjunct Senior Lecturer at Afe Babalola University Ado-Ekiti, Nigeria and Kings University, Ode-omu, Nigeria. Dr. (Barr) Oyedokun- Alli has authored many textbooks in English, Linguistics and Communication skills and has also published in many high-impact Journals. His Research interests are in Sociolinguistics, Applied Linguistics, Discourse Analysis and Forensic Linguistics. He is a member, Linguistic Association of Nigeria; member, Reading Association of Nigeria; member Association for the promotion of Nigerian Languages and Culture. Member Association for the promotion of Development Studies, Nigerian Bar Association; among others. 